\title{
Cyberbullying in Early Adolescence: Is There a Difference Between Urban and Rural Environment?
}

\author{
Dujmic $Z^{1}$, Cosic $\mathbf{V}^{1}$, Rajkovaca ${ }^{1,2}$, Vcev $A^{1}$, Gvozdanovic $Z^{4}$, Miskic $\mathrm{D}^{3}$ and Miskic $\mathrm{B}^{1 *}$ \\ ${ }^{1}$ Faculty of Dental Medicine and Health, University of J.J. Strossmayer, Osijek \\ ${ }^{2}$ Faculty of Medicine, University of J. Juraj Strossmayer, Croatia \\ ${ }^{3}$ General hospital, Slavonski Brod, Croatia \\ ${ }^{4}$ General hospital Nasice, Croatia
}

*Corresponding author: Blazenka Miskic, Faculty of Dental Medicine and Health, University of J.J. Strossmayer, Osijek, Croatia.

To Cite This Article: Dujmic Z, Cosic V, Rajkovaca I, Vcev A, Miskic B, et al., Cyberbullying in Early Adolescence: Is There a Difference Between Urban and Rural Environment?. Am J Biomed Sci \& Res. 2019 - 1(5). AJBSR.MS.ID.000542. DOI: 10.34297/AJBSR.2019.01.000542

Received: February 24, 2019| Published: March 07, 2019

\begin{abstract}
Introduction: Thanks to the availability and possibilities of modern communication technology, new paths of violence have been discovered, which we call cyber bullying. Cyber bullying today represents a serious public health problem.
\end{abstract}

Study goal: To investigate the frequency of internet and cell phone use among urban and rural children and show the extent of bullying among children from 12 to 14 via Internet and mobile phones.

Study design: A cross-sectional study.

Subjects and methodology: Survey included 1295 children from Brodsko-Posavska County. The respondents were students of the sixth, seventh and eighth grade of elementary schools from 12 to 14 years. An anonymous questionnaire related to the children's experience in using the Internet and mobile phones was used.

Results: Internet uses $93.4 \%$ of respondents, of which $59.8 \%$ use the internet on a daily basis. $87.9 \%$ respondents had internet communication. Even $8 \%$ of respondents experienced putting photos on the internet with unpleasant comments. Personal cell phone has $90.1 \%$ of children. $8.3 \%$ of respondents received disturbing and threatening messages via mobile phones. Pornographic or sexual content on the mobile phone was received by $9.3 \%$ of respondents while $15.8 \%$ of respondents photographed or recorded peers in a fight or some other violent behavior.

Conclusion: Research shows the existence of peer violence through the internet and mobile phones. This fact points to the need for prevention that involves systematic education of children, parents and all who work in contact with children.

Keywords: Children, Internet, Cyber Bullying, Prevention

\section{Introduction}

According to the definition of the World Health Organization, violence is "intentional use of physical force and power by threat or action towards oneself, to another person, or to a group of people or the whole community, which results in injury, death, psychological consequences, underdevelopment or deprivation" [1]. Similarly, legislation in Croatia regulated the relationship to domestic violence, and according to the Law on Protection against Domestic Violence, violence is defined as "any form of physical, mental, sexual or economic violence" [2]. Even though violence may seem like a chaotic process, it always has four basic elements: power disproportion, intent of hurting, threats of further aggression, and terribleness that arises as a result of systematic violence used to intimidate other and maintain domination [3].

\section{Cyber Peer Bullying}

Cyber peer bullying is considered as any communication activity of a group or individual via internet, video or mobile phones that serves to the cause of humiliation, teasing, and threats to the victim [4]. Although it occurs primarily in older children and adolescents, it may be present even in children under the age of 8 . Sending cruel, malicious, sometimes threatening messages, as well as creating web pages that contain stories, drawings, images, and jokes on a peer account are characteristics of cyber bullying. Cyber 
bullying also refers to sending photos of peers and asking others to evaluate them by certain characteristics or to vote for a person who is, for example, ugliest, the most unpopular or the fattest in the school. Cyber bullying includes" breaking" in someone else's email and sending malicious and unpleasant content to others. There are two types of cyber bullying: direct attack and attack through mediators [5].

The most common signs of cyber bullying include: reduced selfesteem, anxiety, social isolation, technology-related disturbance, lack of school achievement and impaired health (problems with eating, nightmares, insomnia) [5].

\section{Possible Consequences of Cyber Bullying}

The consequences of cyber bullying can sometimes be much more serious than those caused by peer violence in real situations. A child victim has no control over what is happening, and therefore, although there is no physical contact and physical consequences, the psychological consequences can be very strong and harmful. Victims of cyber bullying can feel as if they are trapped, frustrated and disrupted. Also, they can experience depression, sadness, anger, low self-esteem, suicidal thoughts and stress [5].

\section{Prevention of Cyber Bullying}

Studies conducted over the last twenty years have shown that there are four areas that are successful in reducing cyber bullying [6]. These are: raising awareness, school rules, monitoring and prevention programs. Achieving people's awareness of the problem is one of the first steps in the prevention program. The big problem is denying cyber bullying [7]. School rules should point to nonviolence and define the consequences if such behavior occurs. The rules should be applied daily. The aim of the research was to examine the frequency of internet and cell phone usage among the urban and rural environment of Brodsko - Posavska County and to show the extent of cyber bullying among children aged 12 to 14 via the Internet and mobile phones.

\section{Methods}

The survey was conducted in nine primary schools of Brodsko - Posavina County (three primary schools in urban area and six primary schools in rural area) on a sample of 1295 respondents. The respondents were students of the sixth, seventh and eighth grade from 12 to 14 years. Prior to the implementation of the research, the consent of school principals and parents / guardians of children were obtained. The survey was conducted by a class teacher or an expert associate (psychologist or pedagogue) in the classroom. Upon completing the questionnaire, the students put filled questionnaires in the box to ensure the anonymity of the answers. A questionnaire on children's experiences about the use of the Internet and mobile phones was created for this research. The questionnaire consists of 18 multiple choice questions. The data set was subject to statistical anysis using SPSS (Version 16.0). Categorical data were presented in absolute and relative frequencies. Numerical data were described as mean and standard deviation. The normality of distribution of observed numeric variables was tested by Kolmogorov - Smirnov test. The connection of normally distributed numerical variables was evaluated by Pearson correlation coefficient $r$. The differences between the category variables were tested by the $\chi 2$ test and Fisher's exact test. All $P$ values are two-sided. The level of significance was set at alpha $<0.05$.

\section{Ethical Considerations}

Ethical permission was sought and gained for the study through the local ethics committee and University committee. Copies of which have been retrained for inspection.

\section{Results}

a. The study involved 1295 children, the average age of 13 years (SD 0.9 years). Regarding the place of residence, number of respondents from the city (46.3\%), and respondents living in the village (53.7\%) is equal. There were $632(48.8 \%)$ boys and $663(51.2 \%)$ girls.

b. There is are significantly more respondents without computer from village $(6.1 \%)$ (Fisher's exact test, $\mathrm{p}<0.001)$. Also, 139 (10.8\%) respondents from village has no access to the Internet, significantly more than those living in the city (15.9\%) (Fisher's exact test, $\mathrm{p}<0.001)$. The internet uses 1200 (93.4\%) respondents. They are not using the internet at all or using it several times a month more than one in the village (Table 1).

Table 1: Respondents according to the way of using the Internet and the place of residence.

\begin{tabular}{|c|c|c|c|c|}
\hline \multirow{2}{*}{$\begin{array}{c}\text { Access and } \\
\text { use of the } \\
\text { Internet }\end{array}$} & \multicolumn{3}{|c|}{ Number of $(\%)$ respondents } & \multirow{2}{*}{$\mathbf{p}^{*}$} \\
\hline & Town & Village & Total & \\
\hline \multicolumn{5}{|c|}{ Do you have a computer at home? } \\
\hline No & $12(2)$ & $42(6,1)$ & $54(4,2)$ & \multirow{3}{*}{$<0,001$} \\
\hline Yes & $587(98)$ & $651(93,9)$ & $1238(95,8)$ & \\
\hline Total & $599(100)$ & $693(100)$ & $1292(100)$ & \\
\hline \multicolumn{5}{|c|}{ Do you have internet access at home? } \\
\hline No & $30(5)$ & $109(15,9)$ & $139(10,8)$ & \multirow{3}{*}{$<0,001$} \\
\hline Yes & $569(95)$ & $577(84,1)$ & $1146(89,2)$ & \\
\hline Total & $599(100)$ & $686(100)$ & $1285(100)$ & \\
\hline \multicolumn{5}{|c|}{ Do you use the Internet? } \\
\hline No & $14(2,3)$ & $71(10,3)$ & $85(6,6)$ & $<0,001$ \\
\hline Yes & $585(97,7)$ & $615(89,7)$ & $1200(93,4)$ & \\
\hline Total & $599(100)$ & $686(100)$ & $1285(100)$ & \\
\hline \multicolumn{5}{|c|}{ How often do you use the Interent? } \\
\hline $\begin{array}{c}\text { I don't use it } \\
\text { at all }\end{array}$ & $3(0,5)$ & $16(2,5)$ & $19(1,6)$ & \multirow{5}{*}{$<0,001 \dagger$} \\
\hline $\begin{array}{c}\text { Several } \\
\text { times a } \\
\text { month }\end{array}$ & $36(6,1)$ & $82(12,9)$ & $118(9,6)$ & \\
\hline $\begin{array}{c}\text { Several } \\
\text { times a } \\
\text { week }\end{array}$ & $172(29,3)$ & $183(28,8)$ & $355(29)$ & \\
\hline Everyday & $377(64,1)$ & $355(55,8)$ & $732(59,8)$ & \\
\hline Total & $588(100)$ & $636(100)$ & $1224(100)$ & \\
\hline \multicolumn{5}{|c|}{${ }^{*} \chi 2$ test; $†$ Fisher`s exact test } \\
\hline
\end{tabular}


c. No one is present when respondents are using the internet (40.7\%), and sometimes one of the adults is present in 619 (51.1\%) children. There is no significant difference according to the presence of parents when using the internet.

d. In $566(47 \%)$ of the respondents, parents from the urban areas ban visiting certain websites significantly more than in rural areas (Fisher's exact test, $\mathrm{p}=0.002$ ). Parents of respondents living in the city teach children about dangers on the Internet and how to protect themselves significantly more than parents in rural areas (Fisher's exact test, $p<0.001$ ) (Table 2).

Table 2: Reactions of parents to Internet Use.

\begin{tabular}{|c|c|c|c|c|}
\hline \multirow{2}{*}{} & \multicolumn{3}{|c|}{ Number of (\%) respondents } & \multirow{2}{*}{ p $^{*}$} \\
\cline { 2 - 4 } & Town & Village & Total & \\
\hline \multicolumn{4}{|c|}{ They ban me from going on certain websites } \\
\hline No & $284(48,3)$ & $353(57,4)$ & $637(53)$ & \multirow{2}{*}{0,002} \\
\hline Yes & $304(51,7)$ & $262(42,6)$ & $566(47)$ & \\
\hline Total & $588(100)$ & $615(100)$ & $1203(100)$ & \\
\hline
\end{tabular}

They teach me how to identify dangers on the internet and how to protect myself

\begin{tabular}{|c|c|c|c|c|}
\hline No & $155(26,4)$ & $233(37,9)$ & $388(32,3)$ & \multirow{2}{*}{$<0,001$} \\
\cline { 1 - 3 } Yes & $433(73,6)$ & $382(62,1)$ & $815(67,7)$ & \\
\cline { 1 - 3 } Total & $588(100)$ & $615(100)$ & $1203(100)$ & \\
\cline { 1 - 2 } & &
\end{tabular}

I do not think they are interested in what I do while I'm online

\begin{tabular}{|c|c|c|c|c|}
\hline No & $447(76,4)$ & $483(78,4)$ & $930(77,4)$ & \multirow{2}{*}{0,408} \\
\cline { 1 - 3 } Yes & $138(23,6)$ & $133(21,6)$ & $271(22,6)$ & \\
\cline { 1 - 3 } Total & $585(100)$ & $616(100)$ & $1201(100)$ & \\
\hline
\end{tabular}

*Fisher's exact test.

e. $1063(87.9 \%)$ respondents communicate via the internet (chat, Facebook, forum, blog), significantly more from the city (Fisher's exact test, $\mathrm{p}<0.001$ ). Most of respondents (38.3\%) spend up to 1 hour in socializing and talking to others over the Internet in one visit, significantly longer than respondents from rural areas ( $\chi 2$ test, $\mathrm{p}=0.044$ ) (Table 3 ).

Table 3: Communication via the Internet (Facebook, chat, forum) by place of residence.

\begin{tabular}{|c|c|c|c|}
\hline \multicolumn{3}{|c|}{ Number of (\%) respondents } & \multirow{2}{*}{ p* } \\
\hline Town & Village & Total & \\
\hline
\end{tabular}

Communication with others via the internet (chat, forum, blog)

\begin{tabular}{|c|c|c|c|c|}
\hline No & $40(6,8)$ & $106(17,1)$ & $146(12,1)$ & \\
\cline { 1 - 4 } Yes & $548(93,2)$ & $515(82,9)$ & $1063(87,9)$ & \multirow{2}{*}{$<0,001$} \\
\cline { 1 - 4 } Total & $588(100)$ & $621(100)$ & $1209(100)$ & \\
\cline { 1 - 3 } &
\end{tabular}

How much time do you spend in socializing and talking to others on the Internet in one visit?

\begin{tabular}{|c|c|c|c|c|}
\hline Up to half hour & $165(29,8)$ & $188(35,3)$ & $353(32,5)$ & \\
\cline { 1 - 4 } Up to one hour & $231(41,8)$ & $185(34,7)$ & $416(38,3)$ & \multirow{2}{*}{0,044} \\
\cline { 1 - 3 } $\begin{array}{c}\text { More than } 2 \\
\text { hours }\end{array}$ & $157(28,4)$ & $160(30)$ & $317(29,2)$ & \\
\cline { 1 - 3 } Total & $553(100)$ & $533(100)$ & $1086(100)$ & \\
\cline { 1 - 2 }${ }^{*} \chi 2$ test
\end{tabular}

f. $209(16.1 \%)$ of the respondents, said that somebody wrote untruth about them or published their secrets. In the situation where someone puts their pictures or photographs on the internet with accompanying unpleasant comments, 97 $(8 \%)$ respondents, significantly more respondents from urban areas ( $\chi 2$ test, $p<0.001$ ) experienced it (Table 4).

Table 4: Discomfort from other people over the Internet.

\begin{tabular}{|c|c|c|c|}
\hline \multicolumn{3}{|c|}{ Number of (\%) respondents } & p* \\
\hline Town & Village & Total & \\
\hline
\end{tabular}

Has anyone written about you, published your secrets or falsehood about you?

\begin{tabular}{|c|c|c|c|c|}
\hline Yes & $111(18,5)$ & $98(14,1)$ & $209(16,1)$ & $<0,001$ \\
\hline No & $373(62,2)$ & $456(65,5)$ & $829(64,1)$ & \\
\hline I don't know & $115(19,2)$ & $142(20,4)$ & $257(19,8)$ & \\
\hline Total & $599(100)$ & $696(100)$ & $1295(100)$ & \\
\hline
\end{tabular}

Did anybody put your pictures or movies and made you feel uncomfortable with their comments?

\begin{tabular}{|c|c|c|c|c|}
\hline Yes & $61(10,4)$ & $36(5,8)$ & $97(8)$ & $<0,001$ \\
\hline No & $486(82,7)$ & $505(81,2)$ & $991(81,9)$ & \\
\hline I don't know & $41(7)$ & $81(13)$ & $122(10,1)$ & \\
\hline Total & $588(100)$ & $622(100)$ & $1210(100)$ & \\
\hline
\end{tabular}

Have you ever experienced that someone introduced as you and talked / wrote in your name?

\begin{tabular}{|c|c|c|c|c|}
\hline Yes & $151(25,7)$ & $121(19,5)$ & $272(22,5)$ & 0,021 \\
\hline No & $374(63,6)$ & $417(67)$ & $791(65,4)$ & \\
\hline I don't know & $63(10,7)$ & $84(13,5)$ & $147(12,1)$ & \\
\hline Total & $588(100)$ & $622(100)$ & $1210(100)$ & \\
\hline${ }^{*} \chi 2$ test & \multicolumn{5}{|l}{} \\
\hline
\end{tabular}

Table 5: Respondents according to behavior on the Internet.

\begin{tabular}{|c|c|c|c|c|}
\hline \multirow{2}{*}{} & \multicolumn{3}{|c|}{ Number of (\%) respondents } & \multirow{2}{*}{ p* } \\
\cline { 2 - 4 } & Town & Village & Total & \\
\hline
\end{tabular}

Have you misused someone's name or published other people's privacy and secrets on a chat, blog, or website?

\begin{tabular}{|c|c|c|c|c|}
\hline Yes & $56(9,5)$ & $40(6,5)$ & $96(8)$ & \multirow{2}{*}{0,056} \\
\cline { 1 - 3 } No & $532(90,5)$ & $574(93,5)$ & $1106(92)$ & \\
\hline Total & $588(100)$ & $614(100)$ & $1202(100)$ & \\
\hline
\end{tabular}

Have you put someone's picture or published a movie about someone without permission, in order to mock?

\begin{tabular}{|c|c|c|c|c|}
\hline Yes & $39(6,6)$ & $37(6)$ & $76(6,3)$ & \multirow{2}{*}{0,723} \\
\cline { 1 - 3 } No & $549(93,4)$ & $577(94)$ & $1126(93,7)$ & \\
\hline Total & $588(100)$ & $614(100)$ & $1202(100)$ & \\
\hline
\end{tabular}

Did you misrepresent yourself as someone you know and speak ugly things on their behalf on a chat, blog or website?

\begin{tabular}{|c|c|c|c|c|}
\hline Yes & $37(6,3)$ & $42(6,9)$ & $79(6,6)$ & \multirow{2}{*}{0,728} \\
\cline { 1 - 3 } No & $551(93,7)$ & $571(93,1)$ & $1122(93,4)$ & \\
\cline { 1 - 3 } Total & $588(100)$ & $613(100)$ & $1201(100)$ & \\
\hline \multicolumn{2}{|l}{${ }^{*}$ Fisher`s exact test }
\end{tabular}

g. $96(8 \%)$ of the respondents abused someone's name or published someone's private message. $76(6.3 \%)$ put someone's 
picture or movie without permission in order to ridicule or mock (Table 5).

h. The mobile phone owns 1151 (90.1\%) children, of which $545(47.4 \%)$ living in the city and 606 (52.6\%) living in the village. Disturbing and threatening messages via mobile phones (Fisher's exact test, $\mathrm{p}=0.032$ ) received $96(8.3 \%)$. Pornographic or sexual content on the mobile phone was received by 107 $(9.3 \%)$ respondents (Fisher's exact test, $\mathrm{p}=0.001$ ), significantly more respondents from the city. $40(3.5 \%)$ of the respondents received disturbing or threatening messages (Table 6).

Table 6: Distribution according to disadvantages through cell phones.

\begin{tabular}{|c|c|c|c|}
\hline \multicolumn{3}{|c|}{ Number of (\%) respondents } & \multirow{2}{*}{ p* } \\
\hline Town & Village & Total & \\
\hline
\end{tabular}

Has anyone sent you disturbing and threatening messages via cell phone?

\begin{tabular}{|c|c|c|c|c|}
\hline No & $491(89,8)$ & $566(93,4)$ & $1057(91,7)$ & \multirow{2}{*}{0,032} \\
\cline { 1 - 3 } Yes & $56(10,2)$ & $40(6,6)$ & $96(8,3)$ & \\
\cline { 1 - 3 } Total & $547(100)$ & $606(100)$ & $1153(100)$ & \\
\hline
\end{tabular}

Did anybody send you pornography and sexual content but you did not want it?

\begin{tabular}{|c|c|c|c|c|}
\hline No & $479(87,6)$ & $567(93,6)$ & $1046(90,7)$ & \multirow{2}{*}{0,001} \\
\cline { 1 - 3 } Yes & $68(12,4)$ & $39(6,4)$ & $107(9,3)$ & \\
\hline Total & $547(100)$ & $606(100)$ & $1153(100)$ & \\
\hline
\end{tabular}

Did you send disturbing and threatening messages to someone?

\begin{tabular}{|c|c|c|c|c|}
\hline No & $525(96)$ & $588(97)$ & $1113(96,5)$ & \multirow{2}{*}{0,339} \\
\cline { 1 - 3 } Yes & $22(4)$ & $18(3)$ & $40(3,5)$ & \\
\hline Total & $547(100)$ & $606(100)$ & $1153(100)$ & \\
\hline
\end{tabular}

Have you photographed or recorded a mob of peers in a fight or in other violent behavior?

\begin{tabular}{|c|c|c|c|c|}
\hline No & $453(82,8)$ & $518(85,5)$ & $971(84,2)$ & \multirow{2}{*}{0,226} \\
\cline { 1 - 3 } Yes & $94(17,2)$ & $88(14,5)$ & $182(15,8)$ & \\
\hline Total & $547(100)$ & $606(100)$ & $1153(100)$ & \\
\hline${ }^{*} \chi 2$ test & & \\
\hline
\end{tabular}

Table 7: Distribution according to whom disturbance should be reported.

\begin{tabular}{|c|c|c|c|c|}
\hline & \multicolumn{3}{|c|}{ Number of (\%) respondents } & \multirow{2}{*}{$\mathbf{p}^{*}$} \\
\hline & Town & Village & Total & \\
\hline I do not know & $158(26,4)$ & $117(17,4)$ & $275(21,7)$ & \multirow{8}{*}{$<0,001$} \\
\hline Administrator & $27(4,5)$ & $43(6,4)$ & $70(5,5)$ & \\
\hline $\begin{array}{l}\text { Administrator } \\
\text { and the police }\end{array}$ & $5(0,8)$ & 0 & $5(0,4)$ & \\
\hline $\begin{array}{l}\text { Administrator } \\
\text { and parents }\end{array}$ & $5(0,8)$ & 0 & $5(0,4)$ & \\
\hline Teacher & $126(21)$ & $220(32,8)$ & $346(27,2)$ & \\
\hline $\begin{array}{l}\text { Police and } \\
\text { parents }\end{array}$ & $68(11,4)$ & $3(0,4)$ & $71(5,6)$ & \\
\hline Parents & $205(34,2)$ & $283(42,2)$ & $488(38,4)$ & \\
\hline Someone else & $5(0,8)$ & $5(0,7)$ & $10(0,8)$ & \\
\hline Total & $599(100)$ & $671(100)$ & $1270(100)$ & \\
\hline
\end{tabular}

i. There are $1094(86.1 \%)$ respondents who thinks that they should report inconveniences and threats, while 177 (13.9\%) are of the opinion that no one should report such behavior. Out of the total number of subjects who would not report this behavior, 115 (19.2\%) were out from town, and significantly less $62(9.2 \%)$ from the village ( $\chi 2$ test, $\mathrm{p}<0.001)$. Most respondents $(38.4 \%)$ said that they should report harassment to their parents, $275(21.7 \%)$ do not know to whom report harassment, and $346(27.2 \%)$ would report to the teacher (Table 7).

\section{Discussion}

The study included 1295 children from the Brodsko-Posavska County area. Considering the place of residence, two groups of respondents were compared: the urban and rural environment. There was equal representation of boys (48.8\%) and girls (51.2\%). According to 2011 data, $70 \%$ of households in the Republic of Croatia have a personal computer, which is a significant increase in the last ten years [8]. It is estimated that computer is present in $95.8 \%$ of the respondents' homes. This survey showed that the majority of respondents use internet, $93.4 \%$ of them, as well as girls and boys, and that there was a significantly higher percentage of internet usage among respondents in the city. Similar results show the research conducted by the Zagreb's Child Protection Clinic and Brave Phone in 2008, where 91\% use the Internet, which is an increase compared to the survey conducted in 2004, when it was $83 \%$ [9].

Children are growing up in the virtual world and often know more about computers than their parents. That is why children often use computers and the internet completely outside parental control. Studies also point to parents' ignorance of how much their children are exposed to violence on the Internet [6]. In this study, only $6 \%$ state parental attendance when using the Internet, which is a progress regard to the research carried out by the Zagreb Child Protection Polyclinic and Brave Phone where it was noticed that only $2.5 \%$ reported presence of one parent while using the Internet [9]. Parents who monitor the use of the Internet are equally represented in urban and rural environments.

It is encouraging that most parents ban going to certain pages, warning children of adverse effects and pointing out ways to protect themselves. This is more commonly in respondents who live in the city. Perhaps this is because UNICEF's 2010 study has shown that parents' educational status affects the assessment of the dangers and usefulness of the Internet for children, and it can be assumed that a greater number of highly educated people live in the city [9]. Data obtained through this research point on the popularity and importance of Internet communication, because most respondents state that they communicate over the Internet. However, the data indicate that significantly more respondents from the city use the internet. The worrying fact is that third of children spend more than two hours a day communicating with others on the Internet, and even $38.3 \%$ of them spend up to one hour per day on a single visit, but significantly shorter respondents from the village. Similar results were obtained in a survey conducted in Croatia in 2009, which states that $44 \%$ of children spend more than two hours communicating with others over the Internet. 
The worrying data obtained in the same survey suggests that $16.9 \%$ of children cannot endure more than one day without using Internet communication, which is primarily communicating through Facebook [10]. If we take into account that children spend a great deal of time in school and a large percentage of respondents spend more than two hours on a daily basis communicating with others via the internet, we can only wonder how online social networks affect the lives of children and young people, their social life, socializing with peers, and carrying out obligations. The question is whether the children are neglecting their school and household duties, pets and sports activities because of the use of online social networks? Has the virtual world of youth become a substitute for a physical, real world?

The experience of having someone written false things or revealing their secrets, putting their photos on the internet, had $46.6 \%$ of respondents, but significantly more children from the city. These results are close to the results of the UNICEF research in Croatia from 2010 where it was found that $37.8 \%$ of children were exposed to discomfort by others via the Internet [9]. A survey conducted in the US in 2007 showed that $43 \%$ of internet users aged 10 to 17 were victims of cyber bullying, and one third of them had emotional difficulties [11]. Regard to sex of victims of cyber bullying, the results of many researches are unclear nowadays because some authors find that victims are mostly boys, while others claim that victims are mostly girls, or claim that there is no gender difference [1]. However, this research shows that the significantly more victims are girls.

Analyzing the behavior of respondents to others via the Internet, $20.9 \%$ claims to have misused someone's name or published someone's private message; put someone's photo or movie without permission. Respondents from the urban area did those things more often. The authors of various researches indicate that boys "prefer" physical violence (which is logical in view of the stronger physical constitution and the willingness to take on a leading role in the society), while girls use verbal methods of aggression and they use more relational violence which is characteristic in cyber bullying [12]. But the results of this research show that both boys and girls participate equally. From this research, there is a clear tendency in increasing the occurrence of cyber bullying. The question arises whether it is sufficient prevention implementation. However, we cannot deny that Croatia has made some progress in preventing and suppressing cyber bullying (e.g. UNICEF's School of Violence and Protocol on the Treatment of Violence in Schools).

The mobile phone is also widely used in the younger population and can therefore serve as a source of violence. The number of Croatian households with mobile phones is on a steady rise. Data from 2011 show that $89 \%$ households have at least one mobile device [13]. These data are closely related to this research, in which $90.1 \%$ of respondents have their own cell phone. Out of the total number of children with a cell phone, there are significantly more girls with phones. Better cell phones record sounds and photos, and both abusers and victims, use it for blackmail and threats. Inappropriate content (offenses, threats, content involving violence, and sexual acts) via mobile phones (text messages, photos, pictures, video clips and calls) received $17.6 \%$ of respondents, significantly more respondents from the city.

Analyzing responses by gender, results indicate that boys statistically receive more sexual content messages. This information is interesting because research suggests that boys are more interested in sexuality research than girls, which is a growing interest in this age [1]. However, not every child is traumatized by seeing pornography, nor will it have any visible consequences, but some studies point to possible negative consequences. Disturbing or threatening messages sent $3.5 \%$ of respondents, but the worrying fact is that $15.8 \%$ of respondents took photos or recorded peers in a fight or some other violent behavior without significant differences according to the place of residence, but significantly more boys. The results obtained are similar to the results of Croatian and world research $[1,9]$.

The attitude of most respondents is that unpleasantness and threats need to be reported. However, the worrying fact is that even $13.9 \%$ of respondents think that such behavior should not be reported. Majority of children in town, more boys, think that violence does not have to be reported. Perhaps this is the reason why Croatian and worldwide research has shown that boys will more laugh at this event than girls [1]. Looking at the overall result, the most common answer to the question to whom disturbance should be reported are first and foremost parents and then teachers. It is a positive fact that the majority of respondents answered that harassment should be reported to parents, and yet, it is a worrying fact that $21.7 \%$ do not know to whom would report harassment. From these answers it can be concluded that the most common strategy of dealing with the situation of violence is sharing it with someone else (most often the parent) or avoidance.

\section{Conclusion}

On the results of conducted research, it can be concluded:

a) The internet is used by most respondents, equally girls and boys, but significantly higher percentage among the respondents in urban than the rural area.

b) More than half of respondents use internet on an everyday basis, equally girls and boys, significantly more respondents from the city.

c) Half of the respondents are without supervision and presence of adults while using the Internet.

d) Parents of respondents living in the city teach them more often of importance of identifying dangers on the Internet and how to protect themselves.

e) Most respondents spend 1 hour per day in socializing and talking to others in one visit, significantly more respondents from the city.

f) Discomfort by other via the Internet (the experience that somebody wrote about them or published their secrets, put their photographs on the internet or wrote on their behalf) felt $46.6 \%$ of respondents, significantly more children from the city, while the victims are more significantly more girls. 
g) $20.9 \%$ of boys and girls abused someone's name or revealed someone's private messages, photos, or movies.

h) Most children have their own cell phone, significantly more girls but there is no significant difference between urban and rural environments.

i) Disturbing and threatening messages received 8.3\%.

j) Pornographic or sexual content was received by $9.3 \%$ of respondents, significantly more from the city, and significantly more boys.

k) Disturbing or threatening messages sent $3.5 \%$ of respondents.

l) Significantly more boys take photos or record violent behavior, regardless of their place of residence.

m) Theattitude of mostrespondents is that the inconveniences and threats need to be reported.

n) Most reporters would report harassment to their parents.

\section{References}

1. Buljan Flander G, Kocijan-Hercigonja D, Marko M usluge (2003) Abuse and neglect of children. Zagreb.

2. The Law on Protection from Domestic Violence. Official Gazette no. $137 / 2009,14 / 2010,60 / 2010$.

3. Coloroso B. Violent, (2004) victim and observer. Bios, Zagreb.
4. Hindu S, Patchin JW (2009) Bullying Beyond the Schoolyard. Preventing and Responding to Cayber Bullying.

5. Gini G (2008) Associations between bullying behavior, psychosomatic complaints, emotional and behavioral problems. J PedChild Health 44 (9): 492-497.

6. Krmek M, BuljanFlander G, Hrpka H (2007) Violence among peers on the Internet. In: Kolesarić V (Ed.), Psychology and Violence in Contemporary Society-Proceedings of Scientific Expertise Psychology of Violence and Abuse. Osijek, pp. 125-132.

7. Andreou E. Bully (2001) victim problems and their association with coping behavior in conflictual peer interactions among school-age children. Educational Psychology 21(1): 59-66.

8. Central Bureau of Statistics. Press releases and statistical reports.

9. TomicLatinac M, Nikcevic-Milkovic A (2010) Assessment of the effectiveness of UNICEF's Program for the Prevention of Peer Violence and Abuse. Study Center of Social Work 16(3): 635-657.

10. Kusic S (2010) Online social networking. Life and school 24(10): 103125.

11. Craig W, Harel-Fisch Y, Fogel-Grinvald H, Dostaler S, Hetland J, et al. (2009) A cross-national profile of bullying and victimization among adolescents in 40 countries. Int J Public Health 2(54): 216-224.

12. Prpic I (2006) Violence among girls. Chronology of Social Work 13(2): 315-330.

13. (2010) State Institute for the Protection of the Family, Maternity and Youth. Report on the results of research conducted among children, teachers and parents in the program of prevention of electronic violence "Stop the chain". 